\title{
The Effects of Vasectomy on Testicular Tissue of Mice: Histological Changes and DNA Fragmentation Study
}

\author{
Salman MO' , Al-Wasiti EA ${ }^{\mathrm{a}}$, Thamir KA ${ }^{\mathrm{b}}$, Al-Ani IMc , Al-Salihi $\mathrm{AR}^{\mathrm{d}}$ \\ ${ }^{a}$ Department of Anatomy, College of Medicine, Al-Nahrain University, Baghdad, Iraq \\ ${ }^{b}$ Institute of Embryology Research \& Infertility treatment, Al-Nahrain University, Baghdad, Iraq \\ c Department of Basic Medical Science, Kulliyyah of Medicine, International Islamic University Malaysia, \\ Kuantan, Pahang, Malaysia \\ ${ }^{d}$ The higher institute of infertility diagnosis and assisted reproductive technology, Al-Nahrain University, \\ Baghdad, Iraq
}

\begin{abstract}
Introduction: We aim to investigate the effect of vasectomy on the histology of the testis as well as to evaluate DNA fragmentation in testicular tissue of male mice. Methods: Bilateral vasectomy was performed on 20 mature male mice; 10 control mice underwent sham-operation. After 6 weeks, the testes were evaluated for histological changes and DNA fragmentation by single cell gel electrophoresis (comet assay). Results: Marked alterations were observed in the testes of vasectomized mice, including degeneration of spermatids, thickened basement membrane, dilatation of the seminiferous tubules, exfoliation of germ cells, reduction in the seminiferous cell population, vacuolated appearance of the epithelium in the tubules and marked interstitial fibrosis. Single cell gel electrophoresis showed a highly significant $(\mathrm{P}<0.0001)$ increase in DNA damage among vasectomized mice (46.02\%) compared with control group (\%27.17) after six weeks of operation. Conclusion: Vasectomy induced deterioration in the seminiferous tubules associated with increased testicular cell's DNA fragmentation.
\end{abstract}

KEYWORDS: Vasectomy, comet assay, DNA degeneration, vas deferens.

\section{INTRODUCTION}

Vasectomy is an established method of male sterilization, and permanent birth control in which the vas deferens is surgically clamped, cut, or otherwise sealed and thus prevents the release of sperm when a man ejaculates. It is one of the most common methods of male contraception used worldwide, with the number of sterilized men estimated to be between 40 and 60 million, and is thought to account for between $5 \%$ and $10 \%$ of all contraceptive methods used. ${ }^{1,2}$ Family planning, male vasectomy, contraception, female sterilization and abortion have different issues, religious and ethical challenges in different countries and religions. ${ }^{3,4}$

Vasectomy is a highly effective contraceptive method that can play an important role in reducing a country's population growth. According to United Nations estimates, in 2005, 37 million of reproductive ages were using vasectomy as their method of contraception, accounting for $5.6 \%$, of all contraceptive use. ${ }^{5}$ Over 40,000 men have a vasectomy in UK every

Corresponding author:

Professor Imad M. Al-Ani,

Department of BMS, Kulliyyah of Medicine, International Islamic University,

P.O. Box 141, 25710 Kuantan, Pahang MALAYSIA.

Tel. +60179776014.

E-Mail: imad_alani@yahoo.com year. ${ }^{6}$ Since 1974 , over 18 million Chinese men have undergone vasectomy by the no-scalpel technique. ${ }^{7}$ Today, India is one of the leading nations across the world with regards to the use of no-scalpel vasectomy; ${ }^{8}$ almost $7 \%$ of all Indian couples were sterilized with a total of 6.2 million vasectomies were done in $1976 .{ }^{9}$ Between 1993 and 2004 an estimated 375,000 Iranian underwent the no-scalpel procedure, raising the prevalence of vasectomy from $0 \%$ to $3.5 \%$ in the national contraceptive mix. ${ }^{10}$

It is well known that genetic material for producing protein is located in the deoxyribonucleic acid (DNA). DNA damage may be induced by variety of exogenous and endogenous agents. Single-strand breaks are often a result of attack by reactive oxygen species, and double strand breaks, which are dangerously cytotoxic but occur much less often, can be generated by ionizing radiation ${ }^{11}$ and by the antitumor agent, bleomycin. ${ }^{12}$ Oxidative DNA damage is caused by reactive oxygen species, "ROS". ROS can induce strand breaks, modifications of bases and basic sites in DNA. ${ }^{13}$

Attention has been paid to study the effects of vasectomy on the spermatogenesis; there are different opinions among authors to the effect of vasectomy on the testis. Significant reductions were observed in early and mature spermatid numbers and an increase in the thickness of the seminiferous tubule wall associated with reduced fertility in vasectomized men, 6 with inadequate concentration and motility in human ejaculated sperm. ${ }^{14}$ Several experimental studies in the monkeys, guinea pigs, 
and rats have shown that vasectomy resulted in severe morphological changes in the testis, spermatogenesis deterioration, testicularb degeneration, testicular lesions, absence of spermatids, depleted germ cells and thickening of the basement membrane. ${ }^{15-1}$ Furthermore, there were observed exfoliation of germ cells and vacuolated appearance of the tubular epithelium in mice; ${ }^{19}$ and vacuolization and marked reduction of the germinal epithelium, thickening of the tunica albuginea and widening of the interstitial space of the Mongolian gerbil. ${ }^{20}$ However, other authors did not find alterations in the testes of vasectomized rabbits; ;1,22 rhesus monkeys ${ }^{23}$ and rats. ${ }^{24,25}$

Increased DNA fragmentation was observed in semen samples of men after vasectomy. ${ }^{26}$ Kubota et al, ${ }^{27}$ observed damaged seminiferous tubules, disorder of cellular arrangement, depletion of the germ cells, and local interstitial fibrosis of vasectomized rats. These changes were associated with apoptotic germ cells exhibiting cellular DNA fragmentation. O'Neill et al, ${ }^{28}$ observed reduced sperm yields after vasectomy in men associated with increased apoptosis and increased DNA fragmentation.

The single-cell gel electrophoresis assay (comet assay) was developed as a method to examine DNA integrity and measuring DNA breakage in individual mammalian cells. ${ }^{29,30}$ Heaton et al, ${ }^{31}$ applied comet assay on canine and feline leucocytes and concluded that this method provides a way of assessing levels of DNA damage. They further suggested that it was a useful tool for determining the optimal effects of dietary antioxidants on a reliable biomarkers of oxidative stress such as cellular DNA status in cats and dogs. Simon et al.32 applied comet assay to evaluate DNA fragmentation and semen parameters and found that men with sperm DNA fragmentation at more than a diagnostic threshold of $25 \%$ had a high risk of infertility.

The objectives of this study were to investigate the effects of vasectomy on histological changes that possibly occur in the mice testes and to evaluate DNA damage in the testes using a single cell gel electrophoresis assay.

\section{MATERIALS AND METHODS}

\section{Animals and procedure}

Thirty healthy mature Swiss albino strain male mice (age: 8-12 weeks) were enrolled into this study; they were kept under suitable environmental conditions such as a room temperature that was maintained at about $24 \pm 20 \mathrm{C}$ and exposed to 12 hour/day light program. Standard chew of pellets and water was provided ad libitum.

The mice were divided into two groups; Control group of 10 mice with sham operation, and 20 mice for the vasectomy group (case). Histological and biochemical evaluations of the testes were demonstrated in both groups.

The vasectomy procedure was performed according to Foley. ${ }^{33}$ After six weeks, experimental and control animals were anaesthetized by single intraperitoneal dose of $0.2 \mathrm{ml}$ of ketamine (hydrochloride) $50 \mathrm{mg} / \mathrm{ml}$ concentration and $0.05 \mathrm{ml}$ Xylazine (Rompun 2\%) $23.32 \mathrm{mg} / \mathrm{ml}$ concentration. The abdomens of each group were immediately opened and both testes were removed. Each testiswas bisected into two halves; one half used for gel electrophoresis (comet assay) and the other half processed for morphological study. The experimental animal protocol was conducted in compliance with humane animal care standards outlined in the National Institutes of Health Guide for the Care and Use of Laboratory Animals. The experimental study was approved by Al-Nahrain University with ethic number of $000(M) 00$.

\section{Cell isolation}

Tissue used for gel electrophoresis was minced (after removing the testicle's capsule) into fine pieces in $1 \mathrm{ml}$ cold HBSS (Hank's Balanced Salt Solution) containing $20 \mathrm{mM}$ Ethylenediaminetetraacetic acid (EDTA)/10\% Dimethyl Sulfoxide (DMSO). The settled tissues were removed (5-10 $\mu \mathrm{l})$ and mixed with $75 \mu \mathrm{l}$ LMPA (Low Melting Point Agarose), and centrifuged at $4000 \mathrm{rpm}$ for 30 minutes 2-3 times using cooled centrifuge. For visualization of DNA damage, observations were made of Ethidium bromide ( $\mathrm{EtBr}$ )-stained DNA using a X40 magnification on a fluorescent microscope. ${ }^{29}$

\section{Histological study}

Tissue was fixed in Bouin's solution for 12-16 hours. After fixation, they were washed using many changes of $50 \%$, ethanol to remove the yellow colour of picric acid, dehydrated through graded alcohols and cleared using two changes of xylene and embedded in paraffin wax. A serial sections of $4-5 \mu \mathrm{m}$ thickness was stained by Harris's hematoxylin and eosin.

\section{Statistical Analysis}

Statistical analysis was performed using SPSS software, version 18 (Chicago, Illinois). Results were analyzed using Student's t-test and paired sample t-test to compare the differences between the means of tests and control studies. The results were expressed as mean \pm standard deviation(SD).

\section{RESULTS}

\section{Histological observation}

The seminiferous tubules of the control group show normal components of spermatogenesis lineage cells and supporting Sertoli cells and normal interstitial tissue (Figure 1) 

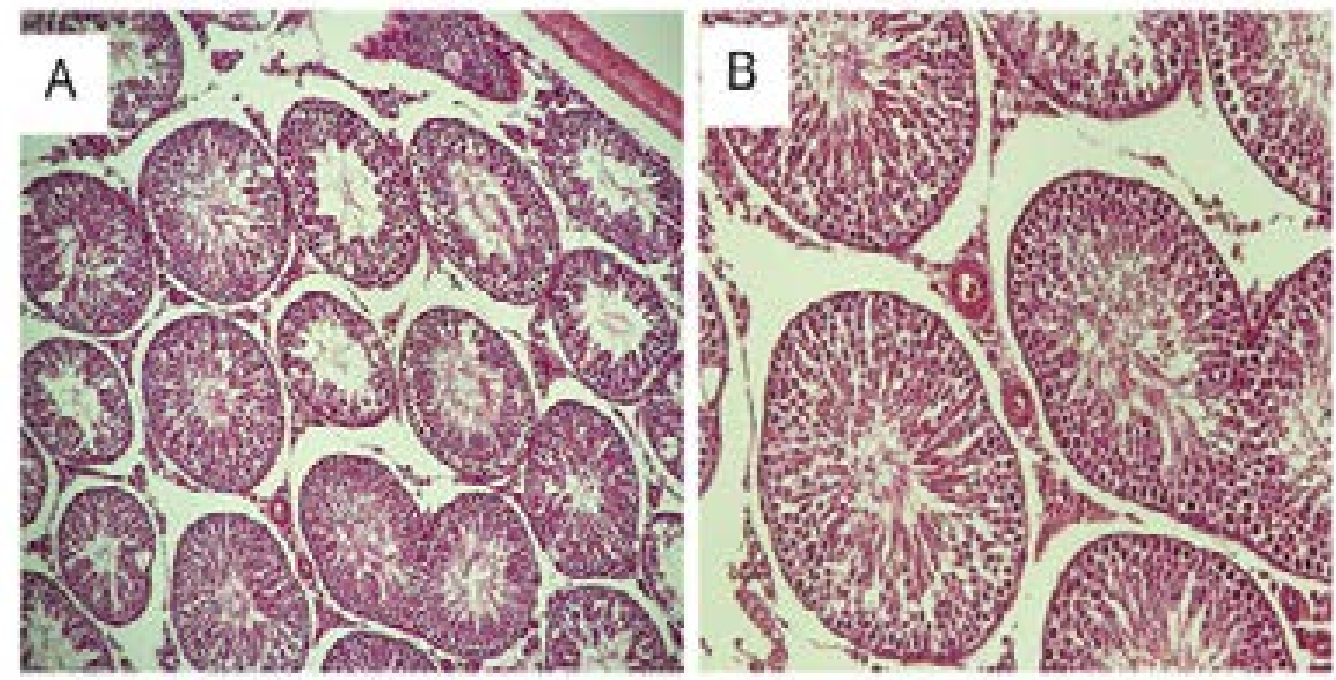

Figure 1. Histological sections of normal mouse testes showing normal seminiferous tubules with spermatogenic cells, Sertoli cell and interstitial cells. (H\&Estain, original magnification “A, x 10; B, x20").

Vasectomized mice showed degenerative changes within the seminiferous tubules; these changes include sloughing of immature germ cells in the tubules, thickening of the basement membrane and vacuolations of the tubules. Some seminiferous tubules had large numbers of spermatids and sloughed spermatogenic cells in their lumen (Figure 2-A). The interstitial tissue of few sections had highly congested blood vessels and large necrotic areas covering some of the tubules together with intertubular eosinophilic material (edema) with scant mononuclear cell's infiltration (Figure 2-B). Disarrangement of some tubules associated with lacking of some stages of germ cells was observed (Figure 2-A \&B). Some tubules were almost completely destroyed (with vacuolations in the spermatogenic cells) leaving large area of interstitial space associated with edema (Figure 2-C). Some testes showed increased amounts of interstitial fibrosis with thickening of the basement membrane and vacuolations of the tubules (Figure 2-D).
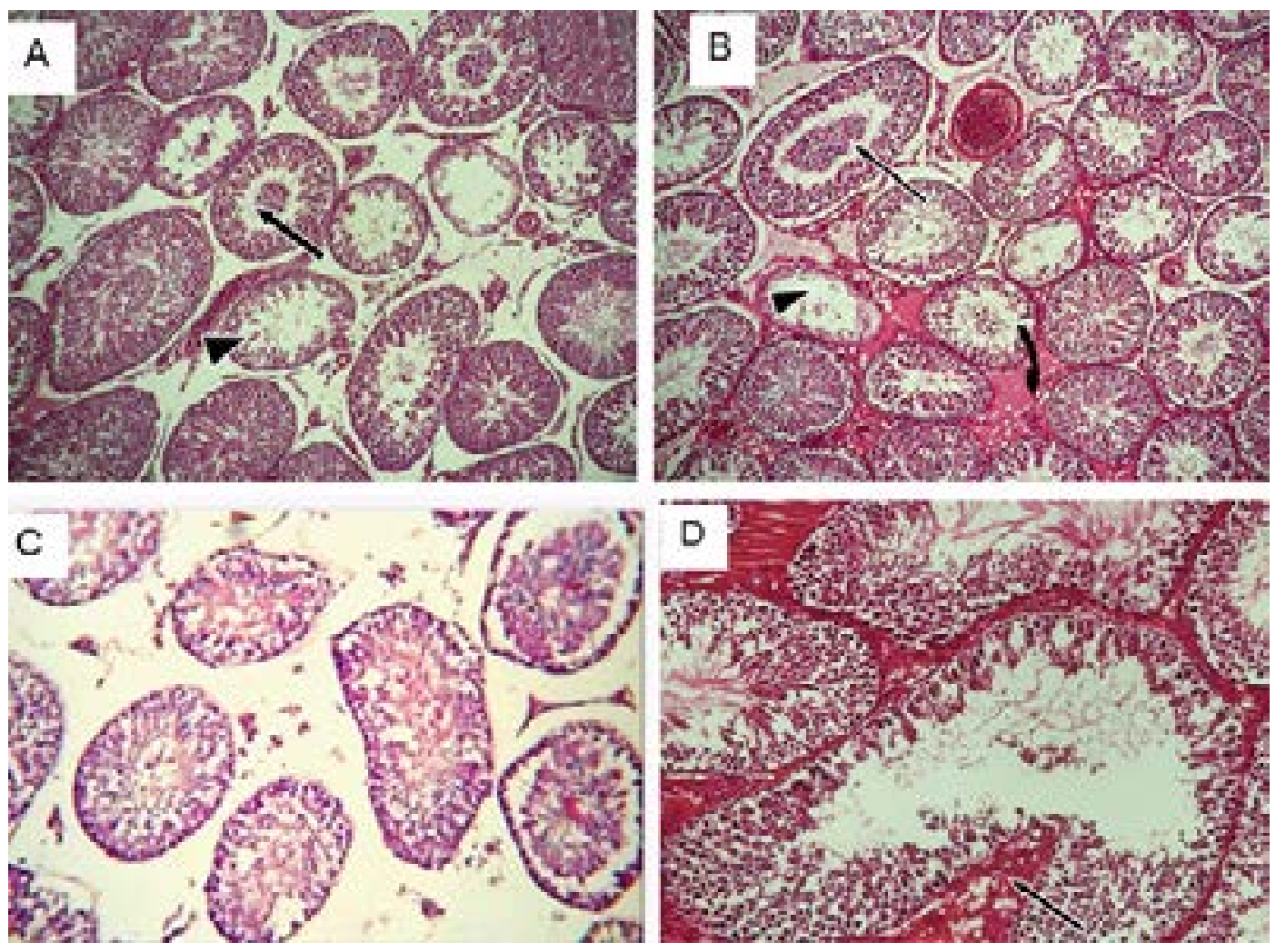

Figure 2. Sample photographs from vasectomized mice testis showing vacuolations of the tubules "head arrow", tubules with sloughed spermatogenic cells and spermatids "arrow" (A \&B), congested blood vessels and large necrotic areas with intertubular eosinophilic material "curved arrow" and scant mononuclear cells infiltration (B), necrotic tubules lacking of some stages of germ cells with vacuolations in the spermatogenic cells (C), interstitial fibrosis "arrow" and thickened basement membranes of seminiferous tubules (D ). ("H \& E stain" original magnification “A, B, C x 10; D, x20"). 
Single cell gel electrophoresis (comet assay)

After six weeks of vasectomy, there was an increase in the percentage of DNA damage in the testicular cells of the vasectomized group compared with the control group. In the present work, 500 cells were counted from the control group, the percentage of cells that showed DNA damage was $27.17 \%$, while in 1000 cells that obtained from the vasectomized group was $46.02 \%$ (Table 1).

Table 1. The means of cells with DNA damage in control and vasectomized groups.

\begin{tabular}{lccccc}
\hline Group & No. of counting cells & $\begin{array}{c}\text { Percentage of cells with } \\
\text { DNA damage }\end{array}$ & SD & t-test & P value \\
\hline Control & 500 & $27.17 \%$ & 1.515 & 13.518 & $0.0001^{*}$ \\
Vasectomy & 1000 & $46.02 \%$ & 2.268 & & \\
\hline
\end{tabular}

*P value reveals highly significant difference of vasectomized groups to their control.

Vasectomized mice showed a significant increase in the mean $( \pm S D)$ comet tail moment compared to their control mice (Table 2). Statistical analysis using independent $\mathrm{t}$-test showed highly significant elevation in the mean comet tail length level in the total cells of the vasectomized group compared to their control group (Table 2).

Table 2. The parameters (tail length, tail moment and percentage of DNA in tail) of comet assay in the vasectomized and control group.

\begin{tabular}{|l|l|l|l|}
\hline Groups & \multicolumn{1}{|c|}{$\begin{array}{c}\text { Tail Length }(\mathrm{px}) \\
\mathrm{X} \pm \mathrm{SD}\end{array}$} & \multicolumn{1}{|c|}{$\begin{array}{c}\text { Tail Moment } \\
\mathrm{X} \pm \mathrm{SD}\end{array}$} & \multicolumn{1}{c|}{$\begin{array}{c}\text { \%DNA in Tail } \\
\mathrm{X} \pm \text { SD }\end{array}$} \\
\hline Control & $5.71 \pm 1.36$ & $0.566 \pm 0.36$ & $5.295 \pm 2.805$ \\
\hline Vasectomy & $33.371 \pm 25.541$ & $8.2 \pm 2.183$ & $16.394 \pm 6.372$ \\
\hline Independent t test & 13.528 & 7.471 & 14.182 \\
\hline P value & $0.0001^{*}$ & $0.0001^{*}$ & $0.0001^{*}$ \\
\hline
\end{tabular}

*P value reveals highly significant difference of vasectomized groups to their control

To support these results, other parameters were used from the comet software (TriTek Comet ScoreTM). Table 3 shows the mean $\pm S D$ of these parameters that include comet length, comet area, comet mean intensity; tail area and tail mean intensity of both two groups. Statistical analysis showed a significant increase in the vasectomized group to all of these parameters of the control group. One parameter that was used to evaluate the intact DNA in the cells obtained from the testes of the control and vasectomized groups, incorporated in the head of comet was the DNA in head \%.

Table 3. The parameters of comet assay in the vasectomized and control groups.

\begin{tabular}{|l|l|l|l|l|l|}
\hline Groups & $\begin{array}{c}\text { Comet } \\
\text { Length (px) } \\
\text { X } \pm \text { SD }\end{array}$ & $\begin{array}{c}\text { Comet Area } \\
(\mathbf{p x}) \\
\mathbf{X} \pm \text { SD }\end{array}$ & $\begin{array}{c}\text { Comet Mean } \\
\text { Intensity } \\
\mathbf{X} \pm \text { SD }\end{array}$ & $\begin{array}{l}\text { Tail Area (px) } \\
\text { X } \pm \text { SD }\end{array}$ & $\begin{array}{l}\text { Tail Mean } \\
\text { Intensity } \\
\text { X } \pm \text { SD }\end{array}$ \\
\hline Control & $\begin{array}{l}41.158 \pm \\
13.202\end{array}$ & $\begin{array}{l}2144.05 \pm \\
161.719\end{array}$ & $\begin{array}{l}24.717 \pm \\
11.387\end{array}$ & $\begin{array}{l}83.131 \pm \\
22.872\end{array}$ & $\begin{array}{l}253.241 \pm \\
105.334\end{array}$ \\
\hline vasectomy & $\begin{array}{l}81.872 \pm \\
36.937\end{array}$ & $\begin{array}{l}4488.358 \pm \\
1126.580\end{array}$ & $\begin{array}{l}30.201 \pm \\
10.058\end{array}$ & $\begin{array}{l}730.71 \pm \\
234.543\end{array}$ & $\begin{array}{l}1326.495 \pm \\
342.506\end{array}$ \\
\hline Independent t test & 14.754 & 7.652 & 6.119 & 5.795 & 4.694 \\
\hline P value & $0.0001^{*}$ & $0.0001^{*}$ & $0.0001^{*}$ & $0.0001^{*}$ & $0.0001^{*}$ \\
\hline
\end{tabular}

${ }^{*} P$ value reveals highly significant difference of vasectomized groups to their control. 
Table 4 shows the mean \pm SD of this parameter, and the statistical analysis showed a highly significant decrease $(p<0.0001)$ of DNA in the head of comet in the vasectomized group as compared with the control group.

Table 4. Percentage of DNA in head of comet assay in the vasectomized and control groups.

\begin{tabular}{|l|l|}
\hline Groups & \%DNA in Head \\
\hline Control & $X^{\prime}{ }^{\prime} \pm$ SD \\
\hline Vasectomy & $94.71 \pm 8.805$ \\
\hline Independent t test & $83.61 \pm 16.372$ \\
\hline P value & 14.182 \\
\hline
\end{tabular}

${ }^{*} \mathrm{P}$ value reveals highly significant difference of vasectomized groups to their control.

\section{DISCUSSION}

The present study has demonstrated an elevation in the percentages of DNA fragmentation associated with abnormal morphology of testicular tissue in vasectomized mice; after six weeks of surgery, there was a significant increase $(P<0.0001)$ in DNA fragmentation of vasectomized group (46.02\%) compared with the control group $(27.17 \%)$.

It is well known that the testis is characterized by very high rates of cell proliferation. Since developing testicular sperm need supportive Sertoli cells, an overabundance of cellproliferation requireselimination of excess germ cells by apoptosis. One characteristic of apoptosis in eukaryotic cells is endonuclease cutting of DNA into discrete sizes. ${ }^{34,35}$ This may explain the presence of low level (27.17\%) of DNAfragmentation among control mice of the present study. The presence of high rate of DNA fragmentation may be related to oxidative stress that is provoked during vasectomy in the case group; this is in accordance with Yamanaka et al, ${ }^{36}$ who related the testicular tissue damage during vasectomy to reactive oxygen species (ROS) exposure. Oxidative stress may significantly impair spermatogenesis and sperm function, which may lead to male infertility. ${ }^{37,38}$ The role of ROS and oxidative stress in the sperm yield of post-vasectomy patients has been shown to be an important cause of male infertility. ${ }^{14,39}$ Seminal oxidative stress is associated with vasectomy reversal, and the ROS-TAC "total antioxidant capacity" score is a possible predictor of infertility after vasectomy reversal. ${ }^{40}$

Jarow et al, ${ }^{41}$ observed focal interstitial fibrosis in men underwent vasectomy; they observed a significant $(P<0.01)$ correlation between interstitial fibrosis and successful vasectomy reversal. Shiraishi et al, ${ }^{42,43}$ detected significant increase in interstitial fibrosis in testicular biopsy; the severity was associated with the period of the obstructive intervals. The present study has demonstrated certain histological changes after vasectomy represented by lacking some stages of germ cells, increase in the sloughing cells, degeneration of spermatids, thickened basement membranes; damaged Sertoli cells, dilatation and necrosis of the seminiferous tubules. Ligation of the vas deferens should increase the pressure within the distal structures and the structure of the tunica albuginea may not allow for expansion to decrease the pressure. The increased pressure may therefore decrease the blood flow to the ipsilateral testis through increasing the intratesticular pressure. ${ }^{44}$ The present histological features may be related to an increase in oxygen free radical, which damage the testicular cells and their DNA, and/or to mechanical effects on the lining of the seminiferous tubule due to increase in hydrostatic pressure. Electron microscopic investigation is in progress to study in detail the ultrastructural changes that occurred in the vasectomized testes.

\section{CONCLUSION}

It is concluded that vasectomy induces histological alteration associated with an increase of DNA damage in the testes and related that to stress.

\section{REFERENCES}

1. Schwingl PJ, Guess HA. Safety and effectiveness of vasectomy. Fertil Steril 2000;73:923-36.

2. Weiske WH. Vasectomy. Andrologia 2001;33:125-34.

3. Albar MA. An Islamic View on Contracep tion and Abortion. JIMA 1989;21:79-82.

4. Akpamu U, Nwoke EO, Osifo UC, Igbinovia ENS, Adisa AW. Knowledge and acceptance of 'vasectomy as a method of 
contraception' amongst literate married men in Ekpoma, Nigeria. Afr J Biomed Res 2010;13:153-6.

5. World Contraceptive Use. New York: United Nations Department of Economic and Social Affairs, 2005.

6. McVicar CM, O’Neill DM, McClure N, et al. Effects of vasectomy on spermatogenesis and fertility outcome after testicular sperm extraction combined with ICSI. Hum Reprod 2005;20:2795-800.

7. Xiaozhang L. Scalpel versus no-scalpel incision for vasectomy: RHL commentary (last revised: 27 July 2009). The WHO Reproductive Health Library; Geneva: World Health Organization.

8. Kaza RC. No-scalpel vasectomy: an overview. J Indian Med Assoc 2006;104: 129-30.

9. Ross JA, Hong $S$ and Huber D. Voluntary Sterilization: An International Fact Book. Association for Voluntary Sterilization, New York, 1985.

10. Country report on the population and fam ily planning program in the Islamic Repub lic of Iran. Teh ran: Ministry of Health and Medical Education, 2007.

11. Lindahl T, Wood RD. Quality control by DNA repair. Science 1999;286:1897-905.

12. Dziegielewski J, Melendy T, Beerman TA. Bleomycin induced alterations in DNA replication: relationship to DNA damage. Biochemistry 2001;40:704-11.

13. Cocuzza M, Sikka SC, Athayde KS, Agarwal A. Clinical relevance of oxidative stress and sperm chromatin damage in male infertility: An evidence based analysis. Int Braz J Urol 2007;33:603-21.

14. McVicar CM, McClure N, Williamson K, Dalzell LH, Lewis SE. Incidence of Fas positivity and deoxyribonucleic acid double-stranded breaks in human ejaculat ed sperm. Fertil Steril 2004;81:767-74.

15. Lohiya NK, Tiwari SN, Ansari AS, Watts N. Long-term vasectomy effects on testis and accessory sex organ function in langur monkey. Acta Eur Fertil 1987;18:207-11.

16. Tung KSK, Alexander NJ. Immunopathologic studies on vasectomized guinea pig. Biol Reprod 1977;17:241-54.

17. Sarrat R, Whyte J, Torres A, Lostalé F, Díaz MP. Experimental vasectomy and testicular structure. Histol Histopathol 1996;11:1-6.

18. Ren $L$, Weng Q, Kishimoto $M$, et al. Effect of short period vasectomy on $\mathrm{FSH}, \mathrm{LH}$, Inhibin and testosteron secretion, and sperm motility in adult male rats. Exp Anim 2011;60:147-56.

19. Singh SK, Chakravarty S. Histologic changes in the mouse testis after bilateral vasectomy. Asian J Androl 2000;2:115-20.

20. Razzoli M, Valsecchi P, Polidori M, Cinquetti Volume 11 Number 2, Dec 2012
R. Testis histology and plasma testosterone levels in the Mongolian gerbil (Meriones unguiculatus) after vasectomy. Ital J Zool 2004;72:9-14.

21. Paufler SK, Foote RH. Spermatogenesis in the rabbit following ligation of the epididymidis at different levels. Anat Rec 1969;164:339-48.

22. Peng B, Wang YP, Shang Y, Guo Y, Yang ZW. Effect of vasectomy via inguinal canal on spermatogenesis in rabbits. Asian $\mathrm{J}$ Androl 2008;10:486-93.

23. Hadley MA, Dym M. Spermatogenesis in vasectomized monkey: quantitative analyses. Anat Rec 1983;205:381-6.

24. McDonald SW, Scothorne RJ. A quantitative study of the effects of vasectomy on spermatogenesis in rats. J Anat 1988;159: 219-25.

25. Golghate T, Naidu SS, Sathe VM, Fulpatil $M P$. The effects of vasectomy on the testes of albino rats: A histological study. Journal of Clinical and Diagnostic Research 2011;5:1514-8.

26. Smit M, Wissenburg OG, Romijn jC, Dohle GR. Increased sperm DNA fragmentation inpatients with vasectomy reversal has no prognostic value for pregnancy rate. J Urol 2010; 183:662-5.

27. Kubota Y, Sasaki S, Kubota H. A study on the mechanism of the spermatogonic damage after vasectomy in rats. Nippon Hinyokika Gakkai Zasshi 2001;92:13-22.

28. O'Neill DA, McVicar CM, McClur N, et al. Reduced sperm yield from testicular biopsies of vasectomized men is due to in creased apoptosis. Fertil Steril 2007;87: 834-41.

29. Singh NP, McCoy MT, Tice RR, Schneider EL. A simple technique for quantitation of low levels of DNA damage in individual cells. Exp Cell Res 1988;175:184-91.

30. Rojas E, Lopez MC, Valverde M. Single cell gel electrophoresis assay: methodology and applications. J Chromatogr B Biomed Sci Appl 1999;722:225-54.

31. Heaton PR, Ransley R, Charlton CJ, et al. Application of single-cell gel electrophoresis (comet) assay for assessing levels of DNA damage in canine and feline

leukocytes. J Nutr 2002;132:1598-603.

32. Simon L, Brunborg $G$, Stevenson $M$, et al. Clinical significance of sperm DNA damage in assisted reproduction outcome. Hum Reprod 2010;25:1594-608.

33. Foley PL. Common surgical procedures in rodents. Office of Animal Research Education and Compliance, University of Virginia, Charlottesville, VA, USA. Laboratory Animal Medicine and Management, Reuter, JD and Suckow, MA (Eds.). International 
Veterinary Information Service, Ithaca NY (www.ivis.org) 2005; Retrieved on January, 2010.

34. Sakkas D, Seli E, Manicardi GC, et al. The presence of abnormal spermatozoa in the ejaculate: did apoptosis fail. Hum Fertil 2004;7:99-103.

35. Agarwal, A, Said TM. Oxidative stress, DNA damage and apoptosis in male infertility: a clinical approach. BJU Int 2005;95:503-7.

36. Yamanaka K, Fujisawa $\mathrm{M}$, Tanaka $\mathrm{H}$, et al. Significance of human testicular mast cells and their subtypes in male infertility. Hum Reprod 2000;15:1543-7.

37. Agarwal A, Makker K, Sharma R. Clinical relevance of oxidative stress in male factor infertility: an update. Am J Reprod Immunol 2008;59:2-11.

38. Tremellen K. Oxidative stress and male infertility, a clinical perspective. Hum Reprod Update 2008;14:243-58.

39. Aitken RJ, Ryan AL, Curry BJ, Baker MA. Multiple forms of redox activity in populations of human spermatozoa. Mol Hum Reprod 2003;9:645-61.

40. Koletti PN, Sharma RA, Pasqualotto FF. Effect of seminal oxidative stress on fertility after vasectomy reversal. Fertil Steril 1999;71: 249-55.

41. Jarow JP, Budin RE, Dym M. Quantitative pathologic changes in the human testis after vasectomy. A controlled study. N Engl J Med 1985;14:1252-6.

42. Shiraishi K, Takihara H, Naito K. Influence of interstitial fibrosis on spermatogenesis after vasectomy and vasovasostomy. Contraception 2002;65:245-9.

43. Shiraishi K, Takihara H, Naito K. Quantitative analysis of testicular interstitial fibrosis after vasectomy in humans. Aktuelle Uro 2003;34: 262-4.

44. Kutlu O, Kocabiyik A, Koksal IT, Guntekin E. Effects of Chemical Sympathectomy on Contralateral Testicular Histology and Fertility in Unilateral Vasectomy. J Korean Med Sci 2009;24:849-52. 